Original Research

\title{
Knowledge, Attitude, and Culture Influence Visual Inspection with Acetic Acid Service Use
}

\author{
Alifina Izza1 ${ }^{1}$, Pungky Mulawardhana ${ }^{2}$, Samsriyaningsih Handayani ${ }^{3}$ \\ ${ }^{1}$ Midwifery Program, Faculty of Medicine Universitas Airlangga \\ 2 Department of Obstetrics and Gynaecology, Faculty of Medicine Universitas Airlangga \\ ${ }^{3}$ Department of Public Health and Preventive Medicine, Faculty of Medicine Universitas Airlangga
}

\begin{abstract}
Introduction: The service use of visual inspection of cervix with acetic acid (VIA) has been low. This technique designed to detect cervical cancer at its earliest stage to prevent the unnecessary burden of its later stages. This study was aimed at showing the influence of knowledge, attitude and culture on the use of VIA service.
\end{abstract}

Methods: This research was a paired case-control study, conducted in 2019 in in the working area of Kalijudan and Mulyorejo Community Health Centers, Surabaya. Ninety eight female respondents of childbearing age were grouped into control and case groups with 49 respondents respectively. Samples were chosen consecutively. Cases were obtained from the health centres' records, while controls were chosen from cases' close neighbours. Interviews were conducted in the respondents' house using closed questionnaires.

Results: The multivariate analysis showed that knowledge $(p<0.001)$, attitudes $(p=0.012)$ and culture $(p=0.045)$ affected the use of VIA early detection services.

Conclusion: This study pointed out that knowledge, attitude and cultural factors were influential factors in the use of VIA early detection services. Health workers may improve women's knowledge and attitude through health promotion, and take into account supportive local cultural factors in the program to enhance the use of VIA.

\section{ARTICLE HISTORY}

Received: August 07, 2020

Accepted: October 23, 2020

\section{KEYWORDS}

visual inspection with acetic acid; women of childbearing age; cervical cancer

\section{CONTACT}

Samsriyaningsih Handayani $\bowtie$ samsri.handayani@gmail.comm $\Longrightarrow$ Department of Public Health and Preventive Medicine Faculty of Medicine Universitas Airlangga

Cite this as: Izza, A., Mulawardhana P., \& Handayani, S.. (2020). Knowledge, Attitude, and Culture Influence Visual Inspection with Acetic Acid Service Use. Jurnal Ners, 15(2). 208 - 213. doi: http://dx.doi.org/10.20473/jn.v15i2.21250

\section{INTRODUCTION}

Visual Inspection with Acetic Acid (VIA) is an examination performed by medical personnel to a cervix on which $3 \%-5 \%$ acetic acid/vinegar acid has been applied to detect cervical cancer. VIA examination is one of the joint programs between the government and the regional office of the Ministry of Health which is regulated in the Minister of Health Regulation No. 34 of 2015 as an effort to prevent noncommunicable disease of cervical cancer which is carried out nationally, including in all districts/cities in East Java. The VIA program is regarded as successful if its implementation can reach $80 \%$ of total women of childbearing age (WCA). In 2016, because WCA who underwent VIA examinations were still far from the target, the number of WCA undergoing VIA examinations was regarded as adequate if it reached $50 \%$ of total WCA. In 2017, because the number of WCs who underwent VIA examinations was still very low, the number of WCA undergoing VIA examinations was regarded as adequate if it reaches $10 \%$ of total WCA (Ministry of Health, 2016). The high incidence of cervical cancer in Indonesia is due to low awareness (less than 5\%) of married women or those who had engaged sexual relations for undergoing early detection.

The Indonesian Ministry of Health (2018) data showed that since 2014 VIA examination had not reached the target. From 6,012,729 women of 
childbearing age (WCA) in East Java in 2017, only $3.81 \%$ of WCA took the test (The Department of Health of East Java Provience, 2016). In the city of Surabaya in 2014 through 2016, WCA taking VIA tests were $0.94 \%, 2.25 \%$ and $1.23 \%$ respectively. In 2018 the average VIA coverage in Surabaya was $6.03 \%$. In the working area of the Mulyorejo Public Health Center, Mulyorejo Subdistrict, 2.13\% were examined, whereas in the working area of the Kalijudan Public Health Center in the same subdistrict (3.80\%) were tested. These were the lowest figures in Surabaya ( the City of Surabaya Department of Health, 2016)

Given the high incidence of cervical cancer, early detection of cervical cancer with VIA method should be carried out seriously. However, the success of the examination scope using VIA method is inseparable from the influence of various factors. The aim of the study was to analyze factors influencing the use of VIA services among women of childbearing age.

\section{MATERIALS AND METHODS}

This study was a paired case control study, aiming to determine factors influencing the use of early detection services of VIA by WCA in the areas of Mulyorejo and Kalijudan Community Health Centers. Population in this study were all WCA in the working area of Kalijudan and Mulyorejo Community Health Centers. Cases were WCA undergone VIA within the past one year, married and lived at the study site, identified through the health centres' records. Controls were WCA had not taken VIA test in the past one year and lived in the same neighborhood with cases and chosen consecutively. The sample size was 49 respondents each for the control and case groups. Data collection was carried out in the working area of Kalijudan and Mulyorejo Community Health Centers, Surabaya, from February to April 2019. Interviews were conducted at respondents' houses. Seven questions to assess knowledge, 9 questions for attitude, and 2 questions for culture were tested for reliability and validity. Cronbach's alphas were 0.412 for knowledge and 0.599 for attitude. Pearson's Product moment correlation for validity yielded pvalues between 0.008 to 0.750 for knowledge and 0.005 to 0.008 for attitude.

\section{RESULTS}

\section{The study findings are presented as follows.}

The age of the respondents in this study ranged from 21 to 66 years old, with its mean of $13.50 \pm$ 11.359 years old. The length of marriage ranged from 1 - 53 years, with the average of $16.18 \pm 11.359$ while the average number of lifetime sexual partners was $1.05 \pm 0.333$. The number of children of the respondents ranged from 0 to 7 children, with the average of $2.27 \pm 1.117$ The first time the respondents had sexual intercourse ranged from the age of 13 to 34 years with mean of $21.72 \pm 3.618$. Continuous data were further dichotomized using mean as cut off value (Table 1)
Responding to question on knowledge, the question most frequently incorrectly answered was at what age VIA is needed, while regarding the attitude that most people answer incorrectly was the assumption that doing VIA is enough only once in a lifetime. Regarding culture, many respondents thought that their environment would suggest that VIA needs to be taken when they get symptoms of cervical cancer. Knowledge was considered good if the total correct answers were $65 \%$ or more and poor if the total correct answers were less than $65 \%$ of the total correct answers expected. Attitudes of respondents were divided into 2 categories namely favorable and unfavorable with the mean as cut off. For culture, it is divided into 2 categories, namely supporting and not supporting. It is said supportive if the total favorable answers were more than $50 \%$ and said to be unsupportive if the total favorable answers were less than $50 \%$ of the expected favorable answers. Bivariate analyses were performed using X2 test to assess the difference of VIA takers and nontakers in the past one year by knowledge, attitude and culture (Table 2) .

Multiple logistic regressions was performed to detect the influence of knowledge, attitude and culture simultaneously on the use of VIA services (Table 3 ). Table 3 shows that the most influential factor of VIA service use is knowledge, although attitude and culture also have significant impact on the use. Those with good knowledge 7.284 times more likely to use VIA service. Subjects with favorable attitude toward VIA 3.864 times more likely to use the service. Those who perceived their culture as supportive toward VIA use were 2.13 more likely to use the service.

\section{DISCUSSION}

\section{Relationship between knowledge and the use of VIA services}

Analysis showed that there was a relationship between knowledge and the use of VIA services. Knowledge itself is the main part that is the basis for a person to do VIA or not, but the sources or media used to increase knowledge about VIA and all things about cervical cancer are currently very easy for us to reach so it is very possible to influence the increase in VIA use. This is related to the theory that the increase in respondent's knowledge is obtained from increased awareness (self-awareness) and interest in disease prevention (Rogers 1974 in Notoatmodjo 2012). This is in accordance with the results of research on mothers who conducted examinations at the Hamparan Perak Public Health Center, Deli Serdang, explaining that there was a significant relationship between knowledge and IVA examination and with good knowledge, the mother would pay attention to her reproductive health so that she would better recognize the signs of symptoms of cervical cancer and are motivated to 
Table 1. Participants' Characteristics

\begin{tabular}{|c|c|c|c|c|c|c|}
\hline \multirow[t]{2}{*}{ Characteristics } & \multicolumn{2}{|c|}{ No VIA } & \multicolumn{2}{|c|}{ Took VIA } & \multirow{2}{*}{ Total } & \multirow{2}{*}{$\mathbf{p}$} \\
\hline & $\mathbf{N}$ & $\%$ & $\mathbf{N}$ & $\%$ & & \\
\hline \multicolumn{7}{|l|}{ Age } \\
\hline$\leq 30$ years & 20 & 40.8 & 12 & 24.5 & 32 & 0.131 \\
\hline$>30$ years & 29 & 59.2 & 37 & 75.5 & 66 & \\
\hline \multicolumn{7}{|l|}{ Education Completed } \\
\hline Elementary School & 13 & 26.5 & 5 & 10.2 & 18 & \\
\hline Junior High School & 5 & 10.2 & 11 & 22.4 & 16 & 0.109 \\
\hline Senior High School & 23 & 46.9 & 26 & 53.1 & 49 & \\
\hline College/university & 8 & 16.3 & 7 & 14.3 & 15 & \\
\hline \multicolumn{7}{|l|}{ Employment } \\
\hline Unemployed & 42 & 85.7 & 38 & 77.6 & 80 & 0.708 \\
\hline Self-employed & 1 & 2.0 & 7 & 14.3 & 8 & \\
\hline Employee & 6 & 12.2 & 4 & 8.2 & 10 & \\
\hline \multicolumn{7}{|l|}{ Marriage Age } \\
\hline$\leq 25$ years & 40 & 81.6 & 39 & 79.6 & 79 & 1.000 \\
\hline$>25$ years & 9 & 18.4 & 10 & 20.4 & 19 & \\
\hline \multicolumn{7}{|l|}{ Lifetime sexual partner } \\
\hline 1 person & 47 & 95.9 & 48 & 98.0 & 95 & 0.603 \\
\hline 2 persons & 1 & 2.0 & 1 & 2.0 & 2 & \\
\hline$\geq 3$ persons & 1 & 2.0 & 0 & & 1 & \\
\hline \multicolumn{7}{|l|}{ Child alive } \\
\hline$\leq 3$ children & 46 & 93.9 & 42 & 85.7 & 88 & 0.317 \\
\hline$>3$ children & 3 & 6.1 & 7 & 14.3 & 10 & \\
\hline \multicolumn{7}{|l|}{ Smoking history } \\
\hline Passive and Active Smokers & 30 & 61.2 & 32 & 65.3 & 62 & 0.834 \\
\hline Not both & 19 & 38.8 & 17 & 34.7 & 36 & \\
\hline \multicolumn{7}{|l|}{ Age of first time having sex } \\
\hline$\leq 20$ years & 24 & 49 & 22 & 44.9 & 46 & 0.840 \\
\hline$>20$ years & 25 & 51 & 27 & 55.1 & 52 & \\
\hline \multicolumn{7}{|c|}{ Relevant symptom of cervical cancer risk factor } \\
\hline 0 & 29 & 59.2 & 24 & 49 & 53 & 0.618 \\
\hline 1 & 10 & 20.4 & 12 & 24.5 & 22 & \\
\hline 2 & 8 & 16.3 & 12 & 24.5 & 20 & \\
\hline 3 & 2 & 4.1 & 1 & 2 & 3 & \\
\hline
\end{tabular}

Table 2. Frequency distribution of knowledge, attitude and culture in VIA takers and non-takers in the past one

\begin{tabular}{|c|c|c|c|c|c|c|}
\hline \multirow[t]{2}{*}{ Dependent Variables } & \multicolumn{2}{|c|}{ No VIA } & \multicolumn{2}{|c|}{ Took VIA } & \multirow[t]{2}{*}{ Total } & \multirow[t]{2}{*}{$\mathbf{P}$} \\
\hline & $\mathbf{n}$ & $\%$ & $\mathbf{n}$ & $\%$ & & \\
\hline \multicolumn{7}{|l|}{ Knowledge } \\
\hline Poor & 38 & 77.6 & 27 & 55.1 & 65 & 0.032 \\
\hline Good & 11 & 22.4 & 22 & 44.9 & 33 & \\
\hline \multicolumn{7}{|l|}{ Attitude } \\
\hline Unfavorable & 24 & 49.0 & 7 & 14.3 & 31 & 0.000 \\
\hline Favorable & 25 & 51.0 & 42 & 85.7 & 67 & \\
\hline \multicolumn{7}{|l|}{ Culture } \\
\hline Not Supportive & 33 & 67.3 & 16 & 32.7 & 49 & 0.001 \\
\hline Supportive & 16 & 32.7 & 33 & 67.3 & 49 & \\
\hline
\end{tabular}


Table 3. Results of multiple logistic regressions of knowledge, attitude and culture on the use of VIA services

\begin{tabular}{|c|c|c|c|c|c|}
\hline \multirow{2}{*}{ Dependent Variables } & \multirow{2}{*}{ B } & \multirow{2}{*}{ Sig. } & \multirow{2}{*}{$\begin{array}{l}\text { Adjusted } \\
\text { OR }\end{array}$} & \multicolumn{2}{|c|}{ 95\% C.I for Adjusted OR } \\
\hline & & & & Lower & Upper \\
\hline Knowledge & 1.986 & $<0.001$ & 7.284 & 2.417 & 21.951 \\
\hline Attitude & 1.352 & 0.012 & 3.864 & 1.354 & 11.030 \\
\hline Culture & 0.756 & 0.045 & 2.130 & 1.017 & 4.462 \\
\hline
\end{tabular}

carry out early detection, and perform early treatment if they are diagnosed with cervical cancer (Sibero and Hanum, 2018). This study is also in accordance with previous research which states that there is a significant relationship between knowledge and IVA examination (Gustiana et al., 2013; Achmad, 2016; Rahayu, 2017; Fauza, Aprianti and Azrimaidaliza, 2019). This is because in the previous 4 studies the characteristics of respondents who became the majority of the sample were the same, namely in women of childbearing age with the majority of housewife and high school education. The theory presented states that the knowledge factor is one of the factors that influence health behavior in society, so that if someone has good knowledge, that person tends to carry out health behavior well, but knowledge is not the only factor that can change behavior a person, but knowledge can also be one of the determinants of changing one's behavior (Notoatmodjo, 2012). Most of a person's knowledge is obtained through the sense of hearing (ears) and the sense of sight (eyes). A person's knowledge of objects also has different intensity or level, so that counseling or information can be done in the mass media as an effort to increase public knowledge about early detection of IVA detection (Notoatmodjo, 2012).

However, someone's knowledge of the object also has different levels of intensity, so that counseling or information can be carried out in the mass media as an effort to increase public knowledge about early detection of VIA.

\section{The relationship between attitude and use of VIA services}

The results of this study indicated relationship between attitude and the use of VIA services. This was in line with previous studies that found a significant relationship between attitude and willingness of women of childbearing age to conduct VIA examinations (Achmad, 2016; Pontoh, Kairupan and Sondakh, 2017; Rahayu, 2017; Silfia and Muliati, 2017; Indrayani, Naziyah and Rahmawati, 2018). The similarity of the finding in this study with that of previous studies was due to the same characteristics of respondents, who mostly were women aged 30 years and not working.

Attitude is a reaction or response that is still closed from a person against a stimulus or object. Manifestations of an indirect attitude can be seen, but can be interpreted in advance of the closed behavior (Notoatmodjo, 2012). Rogers (1974) reveals that before people adopt new behaviours, inside them there occurs sequential stages (Rogers in Notoatmodjo, 2012). The first stage is awareness where the person is aware in the direction of the stimulus (object) or idea. The second stage is interest, that is people start to be attracted to the idea. The third stage is evaluation, where people ponder the benefit and the disadvantage of an idea being offered and whether the idea suits their needs. The fourth stage is trial in which people begin to practice the new idea. The last stage is adoption or rejection, where people adopt or reject the idea.

Nevertheless from subsequent research Rogers conveyed that behavioral changes do not necessarily pass through the above stages. When the acceptance of new behaviour or adoption of behavior through such a process is based on knowledge, awareness and positive attitude, the behaviour will be lasting (long lasting). Preferably if that behavior is not based on knowledge and consciousness then it does not quite last long was similar with it is not enough for the WCA to only have a good level of knowledge about the willingness to conduct a VIA examination, but it must also be reflected in attitude. WCA with a positive attitude will affect its desire to do early detection of cervical cancer with VIA method (Fauza, Aprianti and Azrimaidaliza, 2019). Previous VIA examination can be one of the factors that influence attitudes towards VIA because someone who has already done a VIA examination will do another VIA examination at a later time or can even tell their relatives that the VIA examination is not as scary as imagined (Indrayani, Naziyah and Rahmawati, 2018). This contradicts the statement that there is no significant relationship between attitude and VIA early detection behavior (Situmorang, Winarni and Mawarni, 2016). This can be motivated by behavior that refers to the experience of others or is based on one's own experience. The previous study had different characteristics of respondents, where the level of knowledge and attitudes among the groups studied were significantly different. In addition, a WCA that is positive about something may not necessarily have positive behavior, because a positive attitude will be followed by behavior that refers to the experience of others or is based on the amount of experience a person has. WCA who have negative attitude toward 
early detection of cervical cancer can be related to their ignorance of this information and or do not yet know the purpose and benefits of VIA examination (Rikandi and Rita, 2009). Someone with a good attitude is always expected to have good behavior. However, this is not always the case, so it is expected that the role of local people, including health workers, to continue to encourage WCA who have a good attitude or not to conduct early detection of VIA examination.

This study found that the impact of attitude was lower than knowledge but greater than. Attitude tends to require a relatively shorter time than culture, but funding is one component that is quite dominant in influencing the level of willingness of the WCA to carry out VIA, considering that until now there is still a treatment fee rate and can only be done at a health center which is relatively low. requires road fare.

\section{The relationship between culture and the use of VIA services}

This study showed relationship between culture and WCA's willingness to conduct VIA examinations. This can be due to the fact that in the process of forming a supportive culture towards VIA use takes a very long time considering that community leaders, religious leaders and respected figures in the area are generally men where there is still a tendency to be indifferent to problems regarding female organs so that it is more difficult to increase the willingness to do VIA on WCA.

The relationship was consistent with a study conducted on women of childbearing age at the Jatikalen Community Health Center, Nganjuk Regency, which found that cultural value was a dominant factor for women of childbearing age to undergo an early detection of VIA (Ummiyati, 2017). This was because the research site was still in a province with almost the same customs and habits in its community, especially in terms of health. The results of this study contradicted another previous study which found that there was no significant relationship between culture and WCA's willingness to conduct VIA examinations (Novalina, 2018).

Culture is "the set of distinctive spiritual, material, intellectual and emotional features of society or a social group ... [which] encompasses, in addition to art and literature, lifestyles, ways of living together, value systems, traditions and beliefs" (UNESCO, 2001). Health and wellbeing have been found to be fundamentally influenced by the cultural context (Napier, 2017). In this study, respondents who did not undergo VIA stated that the main reason for not undergoing the examination was because of shame. VIA examination procedures, which require that the pubic part be seen by health workers, are the main reason people do not want to do VIA. The respondents tended to have a culture that does not support VIA examination. They refused to do a VIA examination if there were no external factors that compel those respondents to do so, such as the policy of the health center that all members of Family Welfare
Development (PKK) and women are required to undergo VIA examination (Novalina, 2018). Cultural diversity or someone's interaction with many people who have cultural differences will affect one's beliefs that are reflected in their health behavior (Napier, 2017). Thus it can be concluded that culture is one of the most important components in determining a person's behavior, especially in health behaviors such as VIA early detection examination with VIA. To stimulate community interest in conducting early detection examination, VIA early detection program providers and/or planners should listen, learn from, partner with, and respond to communities that include women of childbearing age, both those who play an active or inactive role in the community (Lee, 2015).

Culture in the communities that likely underestimate a disease also relates to low VIA examination rates. A previous study revealed that, in the case of early detection of cervical cancer, the WCA assumed that if they were healthy or as long as there were no complaints they would not go to a healthcare provider because they thought VIA examination was useless. Therefore, a more active role in every level of society and including in the officials, is needed to more seriously educating public about the importance of undergoing VIA examinations (Nordianti and Wahyono, 2018)

\section{CONCLUSION}

Factors related to the use of VIA services were knowledge about, attitude towards and culture of supporting VIA. Health workers should emphasize the improvement of women's knowledge and attitudes in their work, and take into account local cultural in the program to increase the use of VIA.

\section{REFERENCES}

Achmad, N. (2016) 'Perubahan Pengetahuan Sikap Wanita Usia Subur Deteksi Kanker Serviks dengan Pemeriksaan Metode IVA di Wilayah Kerja Puskesmas Pembangunan Kecamatan Tarogong Kidul Kota Garut Tahun 2016', (November), pp. 112. Available urnal.umj.ac.id/index.php/semnastek.

Indrayani, T., Naziyah and Rahmawati (2018) 'Hubungan Pengetahuan dan Sikap Wanita Usia Subur terhadap Minat Melakukan Iva Test di Puskesmas Kecamatan Jatinegara', JAKHKJ, 4(2).

Lee, S. (2015) 'Cultural Factors Associated with Breast and Cervical Cancer Screening in Korean American Women in the US: An Integrative Literature Review', Asian Nursing Research. Elsevier, 9(2), pp. 81-90. doi: 10.1016/j.anr.2015.05.003.

Napier, A. D. (2017) 'Culture matters: using a cultural contexts of health approach to enhance policymaking', WHO Regional Office for Europe, (1).

Nordianti, M. E. and Wahyono, B. (2018) 'Determinan Kunjungan Inspeksi Visual Asam Asetat di Puskesmas Kota Semarang', HIGEIA JOURNAL OF 
PUBLIC HEALTH, 2(1), pp. 33-44. Available at: http://journal.unnes.ac.id/sju/index.php/higeia.

Novalina, A. (2018) Faktor Yang Berhubungan Dengan Kesediaan Wanita Usia Subur (WUS) Melakukan Pemeriksaan Inspeksi Visual Asam Asetat (IVA) di Dua Wilayah Kerja Puskesmas Kota Surabaya. Universitas Airlangga.

Pontoh, F., Kairupan, B. H. R. and Sondakh, J. (2017) 'Hubungan antara Pengetahuan, Sikap serta Dukungan Keluarga dengan Tindakan Pemeriksaan Payudara Sendiri (Sadari) pada Mahasiswi Semester II Akbid Makariwo Halmahera', (April).

Rahayu, S. (2017) 'Hubungan Tingkat Pengetahuan, Sikap dengan Perilaku Deteksi Dini Kanker Leher Rahim Metode IVA pada Wanita Usia Subur di Dusun Tempuran', 000, pp. 74-84.

Rikandi, M. and Rita, N. (2009) 'Faktor yang berhubungan dengan pemeriksaan dini kanker serviks pada wanita usia subur'.

Silfia, niluh nita and Muliati, T. (2017) 'Hubungan Karakteristik, Pengetahuan dan Sikap dengan Pemeriksaan Inspeksi Visual Asam Asetat (IVA) pada Ibu Pasangan Usia Subur di Puskesmas Talise', CARING, 1(2), pp. 69-83.

Situmorang, M. J., Winarni, S. and Mawarni, A. (2016) 'Hubungan Pengetahuan dan sikap dengan perilaku deteksi dini pada penderita kanker serviks di RSUP dr. Kariadi Semarang tahun 2015', Jurnal Kesehatan Masyarakat, 4(1), pp. 76-82. Available at: http://ejournals1.undip.ac.id/index.php/jkm.

The City Health Office of Surabaya (2016) Profil Kesehatan Kota Surabaya. Surabaya.

The Department of Health of East Java Provience (2016) 'Profil Kesehatan Jawa Timur'.

Ummiyati, M. (2017) Determinan Perilaku Deteksi Dini Kanker Serviks dengan Metode IVA (Inspeksi Visual Asam Asetat) pada Wanita Usia Subur di Puskesmas Jatikalen Kab. Nganjuk. Universitas Airlangga. Available at: http://repository.unair.ac.id/id/eprint/61766.

UNESCO (2001) Universal Declaration on Cultural Diversity, Paris: United Nations Educational, Scientific and Cultural Organization. 